\title{
Effect of Laser Power on Microstructure and Micro-Galvanic Corrosion Behavior of a 6061-T6 Aluminum Alloy Welding Joints
}

\author{
Huiling Zhou ${ }^{1}$, Fanglian Fu ${ }^{1}$, Zhixin Dai ${ }^{2}$, Yanxin Qiao ${ }^{1, * \mathbb{D}}$, Jian Chen ${ }^{1,3, *}$ and Wen Liu ${ }^{1}$ \\ 1 School of Materials Science and Engineering, Jiangsu University of Science and Technology, \\ Zhenjiang 212003, China; zhouhl@just.edu.cn (H.Z.); flfu1997@stu.just.edu.cn (F.F.); \\ liuwen200455@126.com (W.L.) \\ 2 Institute of Metal Research, Chinese Academy of Sciences, Shenyang 110016, China; zxdai16s@imr.ac.cn \\ 3 Department of Chemistry and Surface Science Western, Western University, London, ON N6A 5B7, Canada \\ * Correspondence: yxqiao@just.edu.cn (Y.Q.); jchen496@uwo.ca (J.C.)
}

Citation: Zhou, H.; Fu, F.; Dai, Z.; Qiao, Y.; Chen, J.; Liu, W. Effect of Laser Power on Microstructure and Micro-Galvanic Corrosion Behavior of a 6061-T6 Aluminum Alloy Welding Joints. Metals 2021, 11, 3. https:/ / dx.doi.org/ 10.3390/met11010003

Received: 4 November 2020 Accepted: 21 December 2020 Published: 22 December 2020

Publisher's Note: MDPI stays neutral with regard to jurisdictional claims in published maps and institutional affiliations.

Copyright: () 2020 by the authors. Licensee MDPI, Basel, Switzerland. This article is an open access article distributed under the terms and conditions of the Creative Commons Attribution (CC BY) license (https: / / creativecommons.org/ licenses/by/4.0/).

\begin{abstract}
The 6061-T6 aluminum alloy welding joints were fabricated using gas metal arc welding (GMAW) of various laser powers, and the effect of laser power on the microstructure evolution of the welding joints was investigated. The corrosion behaviors of 6061-T6 aluminum alloy welding joints were investigated in $3.5 \mathrm{wt} \% \mathrm{NaCl}$ solution using scanning electron microscopy (SEM) and energy-dispersive X-ray spectroscopy (EDS). The results showed that the micro-galvanic corrosion initiation from $\mathrm{Mg}_{2} \mathrm{Si}$ or around the intermetallic particles (Al-Fe-Si) is observed after the immersion test due to the inhomogeneous nature of the microstructure. The preferential dissolution of the $\mathrm{Mg}_{2} \mathrm{Si}$ and $\mathrm{Al}-\mathrm{Fe}-\mathrm{Si}$ is believed to be the possible cause of pitting corrosion. When the laser power reached $5 \mathrm{~kW}$, the microstructure of the welded joint mainly consisted of Al-Fe-Si rather than the $\mathrm{Mg}_{2} \mathrm{Si}$ at $2 \mathrm{~kW}$. The relatively higher content of Al-Fe-Si with increasing in laser power would increase the volume of corrosion pits.
\end{abstract}

Keywords: 6061 aluminum alloy; welding; micro-galvanic corrosion; intermetallic particles

\section{Introduction}

The 6061 aluminum alloy is an Al-Mg-Si alloy with good plasticity [1], low density [2], high strength [3,4], great formability [5], and excellent corrosion resistance [6,7]. These advantages enable the aluminum alloy to be widely used in the industry. The traditional welding of aluminum alloy was limited due to the problems that happened in the welding process, including low efficiency, oxide removal, and the burning loss of alloy elements with a low boiling point [8]. Since aluminum alloys are difficult to be welded $[9,10]$, they are usually joined by tungsten inert gas welding ( TIG ) welding [11], friction stir welding (FSW) [12], and laser welding [13]. Hybrid laser-gas metal arc welding (GMAW) is a new welding technique to join aluminum alloy, it takes the benefits of deep penetration of laser, high speed, and low heat input, and combines the arc source to bridge gaps and change the mechanical properties by using the filler wire [10]. Research studies on aluminum alloys in the welding process are mostly focused on formability and the optimization of process parameters.

The published work on the laser-GMAW is mainly focused on the welding mechanism and numerical simulation. Xu et al. [14] established a three-dimensional transient model to investigate the weld pool behavior of aluminum alloy for a horizontal fillet joint by using hybrid laser-melt inert-gas welding (MIG) fillet welding, and they reported that the deformation in the weld pool surface appeared due to the strong downward flow driven by gravity and arc pressure. Xu et al. [15] study the residual stress and distortion of a 6061-T6 joint welded by using laser-gas metal arc welding and found that when the residual stress in and surrounding the weld zone was higher, a large distortion would appear in the middle and rear part of the welding joint. Cao et al. [16] investigated 
the temperature field and fluid flow of a lap joint in the laser-GMAW hybrid welding process and found that the temperature gradient of the sheet decreased from the top to the bottom; the fluid flow governed by droplet impingement force was outward, while it became counterclockwise when it was driven by Marangoni force and gravity. Atabaki et al. [17] use a numerical finite element model to simulate an aluminum alloys joint prepared using laser arc welding and found that the off-distance between the laser beam and arc source and shoulder width would affect the penetration depth and the geometry of the welding joints. Ahmad et al. [18] reported that the post-weld heat treatment could improve the mechanical properties of AA6061 welded joints prepared using gas metal arc welding. Xu et al. [19] found the porousness of the 6061 aluminum alloy welded by laser-GMAW decreased with the increase of arc power. Chu et al. [20] found that the ratio of equiaxed dendrites was proportional with the weld strength, the cube texture in the columnar dendrites would decrease the weld strength, and the weld metal exhibited the characteristic of ductile fracture.

Zhang et al. [21] investigated the corrosion behavior of the weld zone of the AA6061-T6 aluminum alloy in $70 \% \mathrm{HNO}_{3}$, and they found that the corrosion behaviors of the samples were mainly due to the galvanic corrosion couplings between the precipitates and the matrix. Mujibur Rahman et al. [22] examined the galvanic corrosion of an AA6061 welding joint and found that the reason is due to the difference of corrosion potential between the weld fusion zone and the substrate; the dissolution of the surface film and the increase of intermetallic particles aggravated the corrosion of the weld zone. Gharavi et al. [23] found that the increase of intermetallic phases in the weld zone would increase the galvanic corrosion couplings, contributing to the corrosion of AA 6061-T6 aluminum alloy weld zone.

However, the influence of laser power on the corrosion of 6061-T6 aluminum alloy welding joint is still rarely reported. The present work aims to acquire the 6061-T6 welding joints at different laser power by using laser-GMAW and investigate the microstructure of the weld and its corrosion behavior in $3.5 \mathrm{wt} \% \mathrm{NaCl}$ solution.

\section{Experimental}

The materials used in the present study are 6061-T6 aluminum alloy plates with a dimension of $60 \mathrm{~mm} \times 100 \mathrm{~mm} \times 6 \mathrm{~mm}$, and the filler material is ER5356. The chemical composition of these materials is listed in Table 1 . The experimental welding equipment is the welding system is composed of an IPG YLS-6000W fiber $\mathrm{CO}_{2}$ laser and a gas metal arc welding (GMAW) heat source. The operating laser power was $2,3.5$, and $5 \mathrm{~kW}$, respectively. A detailed description of the welding experimental procedure is given elsewhere [24]. The welding joints were cut into small pieces with the dimension of $10 \mathrm{~mm} \times 10 \mathrm{~mm}$, as shown in Figure 1. The samples were ground on SiC papers up to 2000 grit and then polished using diamond polishing paste. The polished samples were cleaned with ethanol, degreased by ultrasonic wave, and air dried.

Table 1. The chemical composition (wt\%) of 6061-T6 aluminum alloy and ER5356.

\begin{tabular}{cccccccccc}
\hline & $\mathbf{S i}$ & $\mathbf{F e}$ & $\mathbf{C u}$ & $\mathbf{M n}$ & $\mathbf{M g}$ & $\mathbf{C r}$ & $\mathbf{Z n}$ & $\mathbf{T i}$ & $\mathbf{A l}$ \\
\hline 6061 aluminum alloy & 0.50 & 0.7 & 0.45 & 0.15 & 1.0 & 0.25 & 0.25 & 0.15 & Bal. \\
ER5356 & 0.25 & 0.4 & 0.1 & 0.11 & 4.9 & 0.065 & 0.1 & 0.11 & Bal. \\
\hline
\end{tabular}

For metallographic observation, the specimens were etched by Keller's reagent ( 1 vol. $\%$ $\mathrm{HF}, 1.5$ vol. $\% \mathrm{HCl}, 2.5$ vol. $\% \mathrm{HNO}_{3}$, and 95 vol. $\% \mathrm{H}_{2} \mathrm{O}$ ) for $1 \mathrm{~min}$. The microstructure and corrosion morphology of the samples were characterized using VHX-900 (KEYENCE, Co. Ltd., Osaka, Japan) an ultra-depth three-dimensional microscope, scanning electron microscope (SEM, JSM-6480, Takeno, Japan), and OXFORD energy dispersive spectrometer (EDS).

The immersion tests of the welding joints were performed in a $3.5 \mathrm{wt} \% \mathrm{NaCl}$ solution at $25 \pm 1{ }^{\circ} \mathrm{C}$ (controlled by a thermostat water bath). The details of the immersion and 
test was described elsewhere [25]. The samples for corrosion test were sealed with 703 silicone rubber, and only the weld region was exposed. The immersion periods are 20, 100, and $240 \mathrm{~h}$, respectively.

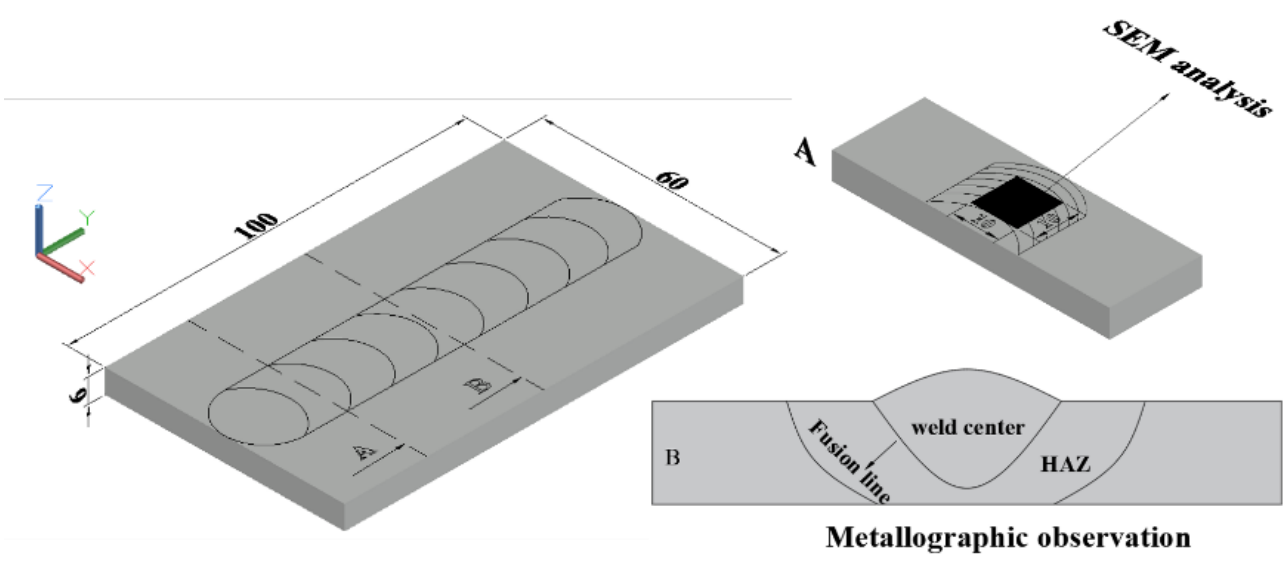

Unit: mm

Figure 1. Schematic of 6061-T6 aluminum alloy welded joint.

\section{Results and Discussion}

\subsection{Microstructure of the Welding Joints}

The typical microstructure of the 6061 aluminum alloy welding joint prepared by using different laser power is shown in Figures $2-4$. It can be seen that the microstructure in the weld center was equiaxed dendrites, while the columnar crystals were found in the fusion zone. At the fusion line, the temperature gradient $(G)$ was the highest and the growth rate $(R)$ was the minimum, resulting in the highest undercooling degree $(G / R)$. Under this circumstance, the columnar crystal was formed in the fusion zone and tended to grow in the direction of heat flux. After an increase in the distance from fusion line, the ratio of $G / R$ decreased, leading to the evolution from columnar crystals to equiaxed dendrites in the weld center [10,26-28].

When the laser power was increased, the morphology of these crystals in the welding joints was similar, but the grain size and dendrites spacing increased. This was mainly because an increase in laser power would increase the heat input and decrease the cooling rate of the weld pool, contributing to the growth of these crystals $[29,30]$.
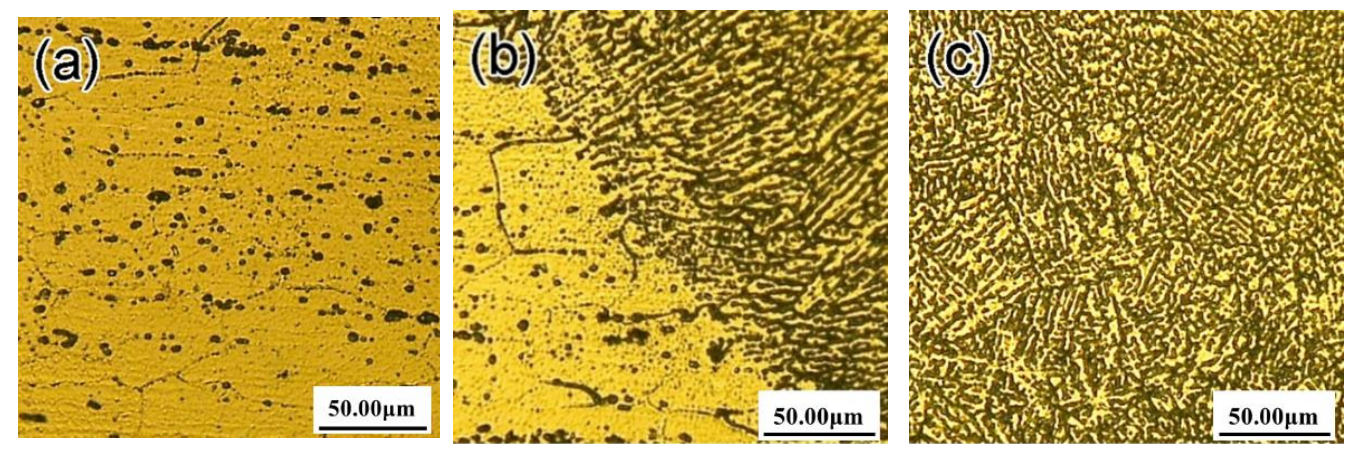

Figure 2. Microstructure of welded joint at 2 kW: (a) Heat-affected zone; (b) Fusion zone; (c) Weld center. 

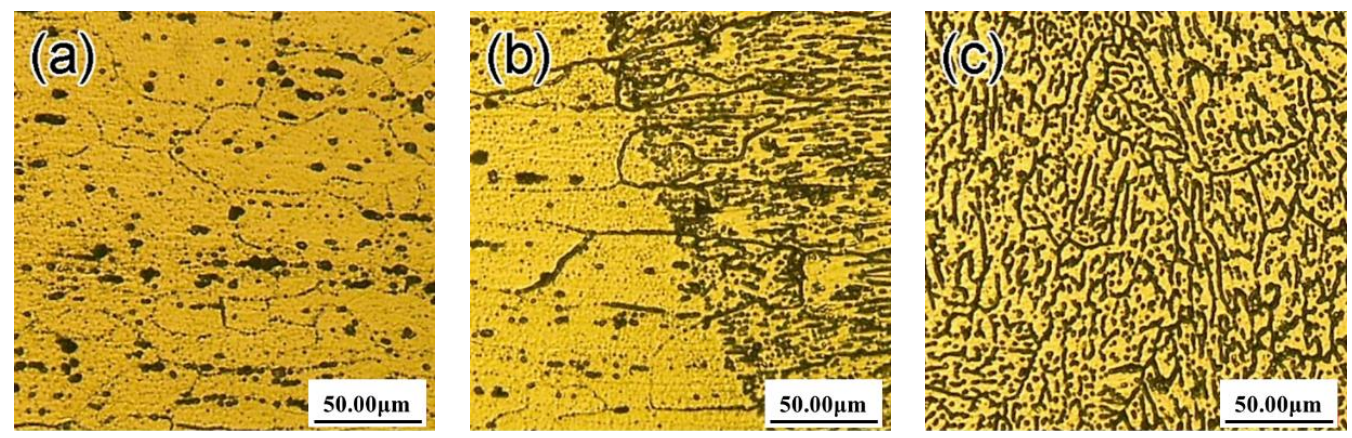

Figure 3. Microstructure of welded joint at $3.5 \mathrm{~kW}$ : (a) Heat-affected zone; (b) Fusion zone; (c) Weld center.
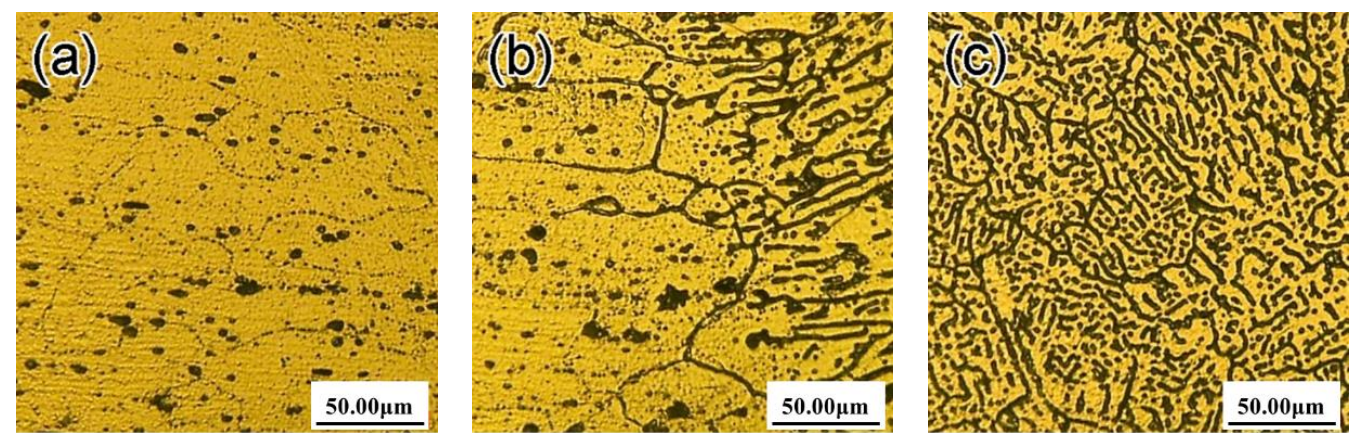

Figure 4. Microstructure of welded joint at $5 \mathrm{~kW}$ : (a) Heat-affected zone; (b) Fusion zone; (c) Weld center.

\subsection{Corrosion Behavior of the Weld Center}

Figure 5 shows the corrosion morphologies of the samples prepared by different laser power after immersion in $3.5 \mathrm{wt} \% \mathrm{NaCl}$ solution. A large number of corrosion pits with different shapes and diameters can be observed on the surface of samples. Similar results are reported for other aluminum alloys, such as AA 5083 [31], AA 6061 [23], and 7A09 $\mathrm{Al}-\mathrm{Zn}-\mathrm{Mg}-\mathrm{Cu}$ alloy [32]. With increasing laser power, the size of the corrosion pits and the number of bright particles (zone B in Figure 4c) both increase.

Figure 6 presents the energy-dispersive X-ray spectroscopy (EDS) analysis of the regions shown in Figure 5. The chemical composition in regions indicated in Figure 5 is listed in Table 2. It showed that zone A was mainly enriched with $\mathrm{Mg}$ and $\mathrm{Si}$, while zone B was enriched with Fe and Si. It can be referred that the second phases in the welded joint are $\mathrm{Mg}_{2} \mathrm{Si}$ phase and Al-Fe-Si phase. This is consistent with the well-recognized principle that the main type of intermetallic inclusions of 6061-T6 aluminum alloy is the iron-rich phase (Fe-Al-Si) and $\mathrm{Mg}_{2} \mathrm{Si}[23,24,33,34]$. The localized corrosion was associated with the dissolution of the $\mathrm{Mg}_{2} \mathrm{Si}$ phase [32] and the Fe-rich intermetallic phase of the multiphase particle [14]. When the laser power is $2 \mathrm{~kW}$, the corrosion pits are small and densely distributed. When the laser power increases, the diameter and volume of the corrosion pits increased significantly, but the number of corrosion pits is dramatically decreased. When prolonging the immersion time, the micro-galvanic corrosion occurring in the $\mathrm{Mg}_{2} \mathrm{Si}$ phases and surrounding particular types of $\mathrm{Al}-\mathrm{Fe}-\mathrm{Si}$ intermetallic phases is aggravated, leading to the increase of pit size. 


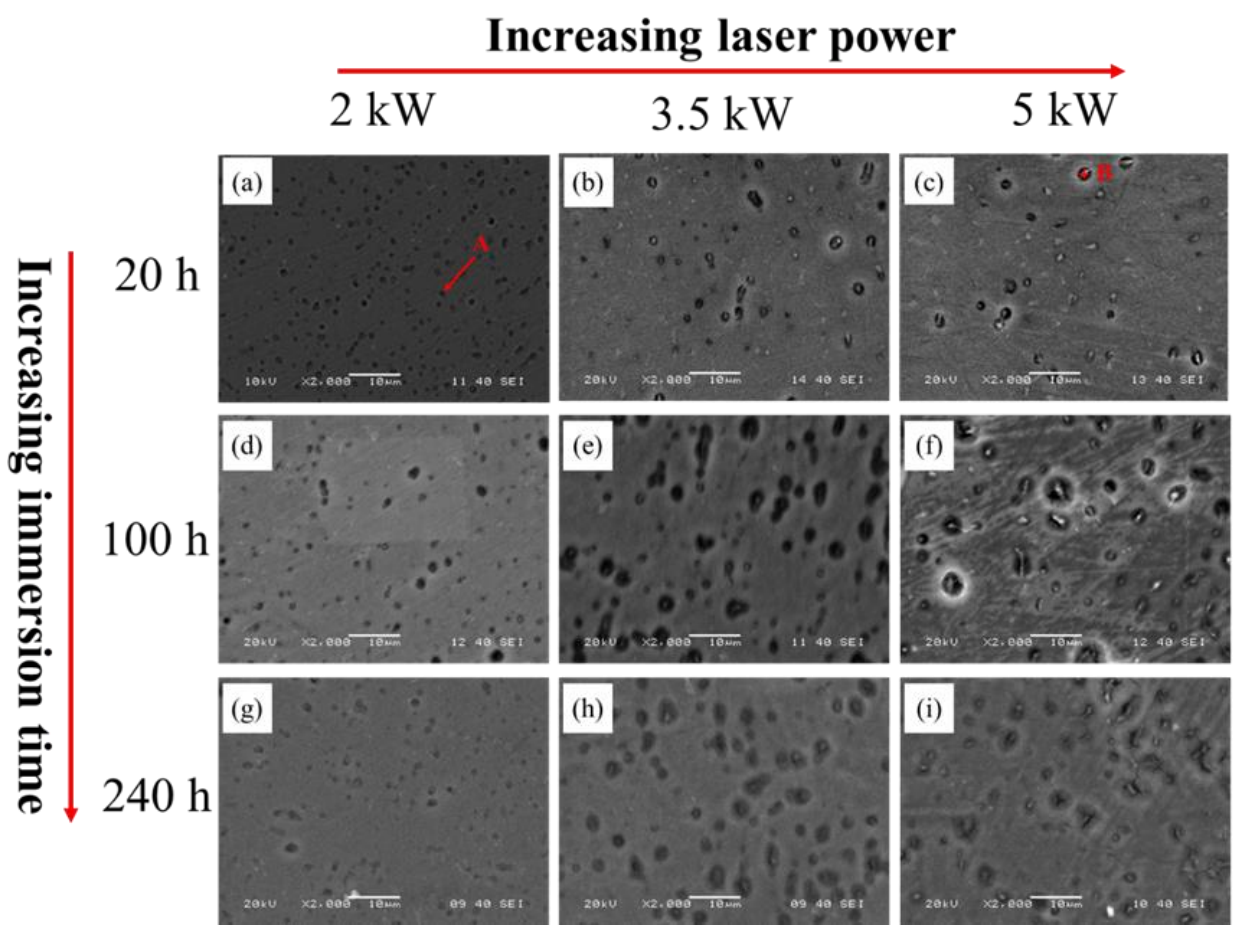

Figure 5. Corrosion morphologies of weld center of 6061 aluminum alloy after immersion in $3.5 \mathrm{wt} \%$ $\mathrm{NaCl}$ solution. (a) $2 \mathrm{~kW}$ and immersiom time $20 \mathrm{~h}$, (b) $3.5 \mathrm{~kW}$ and immersion time 20h, (c) $5 \mathrm{~kW}$ and immersion time $20 \mathrm{~h}$, (d) $2 \mathrm{~kW}$ and immersiom time $100 \mathrm{~h}$, (e) $3.5 \mathrm{~kW}$ and immersion time $100 \mathrm{~h}$, (f) $5 \mathrm{~kW}$ and immersion time $100 \mathrm{~h},(\mathrm{~g}) 2 \mathrm{~kW}$ and immersion time $240 \mathrm{~h}$, (h) $3.5 \mathrm{~kW}$ and immersion time $240 \mathrm{~h}$, (i) $5 \mathrm{~kW}$ and immersion time $240 \mathrm{~h}$.

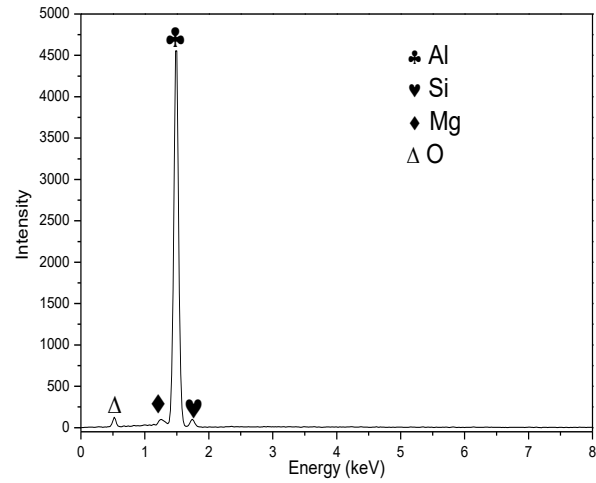

(a)

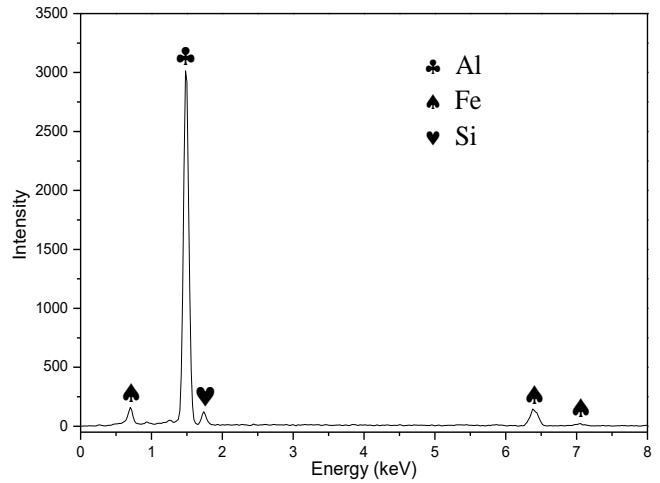

(b)

Figure 6. Energy-dispersive X-ray spectroscopy (EDS) analysis of the regions shown in Figure 4. (a) Zone A, (b) Zone B.

Table 2. The chemical composition ( $(\mathrm{wt} \%)$ in regions indicated on Figure 4.

\begin{tabular}{cccccc}
\hline & $\mathbf{M g}$ & $\mathbf{A l}$ & $\mathbf{S i}$ & $\mathbf{M n}$ & $\mathbf{F e}$ \\
\hline area A & 2.22 & 95.17 & 2.61 & - & - \\
area B & 2.22 & 94.41 & 1.58 & - & 1.79 \\
\hline
\end{tabular}

The corrosion behavior of aluminum alloy in a solution depends mainly upon the potential difference between the intermetallic particle and the aluminum matrix [24,35-38]. On the basis of the surface characterization of the evolution in the surface morphologies of the samples with the immersion time (Figure 5), it can be stated that the corrosion process 
of 6061-T6 aluminum alloy after immersion in $3.5 \mathrm{wt} \% \mathrm{NaCl}$ solution can be associated with the chemical and anodic electrochemical activity of the intermetallic phases. The microgalvanic corrosion process in 6061-T6 alloy is summarized in Figure 7. The precipitated phase of 6061-T6 aluminum alloy is $\mathrm{Mg}_{2} \mathrm{Si}$ and Al-Fe-Si phase. The corrosion potential of 6061-T6 aluminum matrix, Al-Fe-Si intermetallic, and $\mathrm{Mg}_{2} \mathrm{Si}$ intermetallic is about $-700 \mathrm{mV}_{\mathrm{SCE}}$ [24], $-200 \mathrm{mV}_{\mathrm{SCE}}$ [38,39], and $-1200 \mathrm{mV}_{\mathrm{SCE}}$ [36], respectively. The corrosion potential of $\mathrm{Mg}_{2} \mathrm{Si}$ phases is much lower than the potential of their adjacent aluminum substrate. The large potential difference makes the micro-couple action more obvious and prone to galvanic corrosion, in which the low potential $\mathrm{Mg}_{2} \mathrm{Si}$ phases act as anodes in the corrosion process, take priority in dissolving, and form corrosion pits at $\mathrm{Mg}_{2} \mathrm{Si}$. The $\mathrm{Mg}_{2} \mathrm{Si}$ can be hydrolyzed by water according to the following reaction [38]:

$$
\mathrm{Mg}_{2} \mathrm{Si}+4 \mathrm{H}_{2} \mathrm{O} \rightarrow 2 \mathrm{Mg}(\mathrm{OH})_{2}+\mathrm{SiH}_{4}
$$
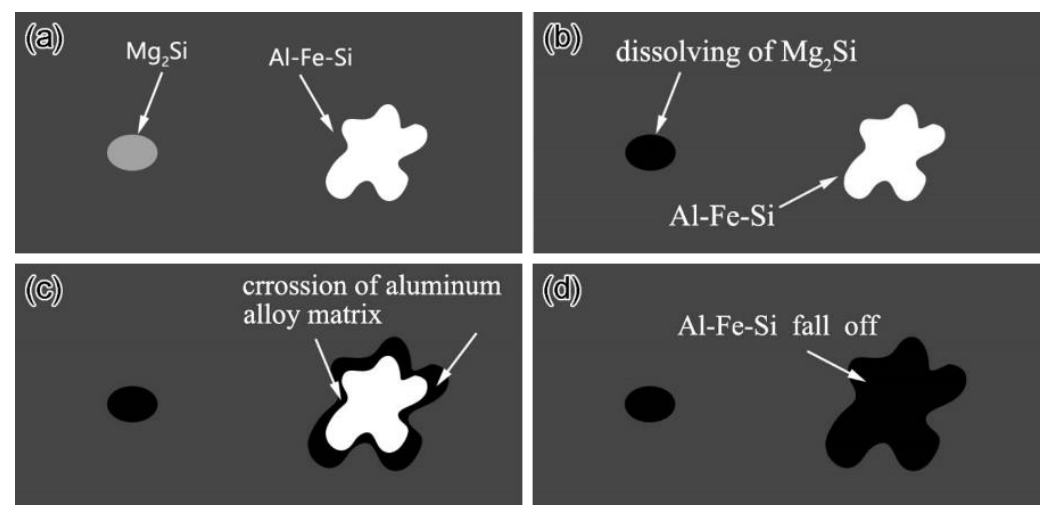

Figure 7. Schematics showing the micro-galvanic corrosion process for 6061-T6 aluminum alloy in $3.5 \mathrm{wt} \% \mathrm{NaCl}$ solution. (a) 6061-T6 alloy, (b) corrosion was initiated on $\mathrm{Mg}_{2} \mathrm{Si}$, (c) Al-Fe-Si was corroded, (d) dissolution and fall off for Al-Fe-Si.

With increasing immersion time, the $\mathrm{Mg}_{2} \mathrm{Si}$ became smaller and smaller until it finally disappears. Unlike the $\mathrm{Mg}_{2} \mathrm{Si}$ phase, the corrosion potential of the Al-Fe-Si phase is noble compared with that of the aluminum alloy matrix. The galvanic coupling between the $\mathrm{Al}-\mathrm{Fe}-\mathrm{Si}$ phase and the surrounding aluminum alloy matrix leads to the severe localized attack. As a result of the obvious potential difference between the Al-Fe-Si phase and aluminum alloy matrix, the corrosion rate of the matrix is faster.

Increasing laser power will bring an increase in the heat input of the weld pool and decrease the cooling rate, which is contributing to an increase of the solid solubility of the $\mathrm{Mg}_{2} \mathrm{Si}$ phase. Under these circumstances, the number of $\mathrm{Mg}_{2} \mathrm{Si}$ phases decreases with the increasing laser power. However, the Al-Fe-Si phase is still insoluble in the matrix with the increase of heat input $[40,41]$. Therefore, when the laser power is $5 \mathrm{~kW}$, the microstructure of weld center is mainly composed of the Al-Fe-Si phase, rather than the $\mathrm{Mg}_{2} \mathrm{Si}$ phase at $2 \mathrm{~kW}$. The variation of potential among the matrix, $\mathrm{Mg}_{2} \mathrm{Si}$, and the Al-Fe-Si phase leads to the dissolution of the $\mathrm{Mg}_{2} \mathrm{Si}$ phase and the matrix surrounding the Al-Fe-Si phase. When the matrix around the Al-Fe-Si phase continues to dissolve, the Al-Fe-Si particles will fall off from the matrix and form bigger pits. The relative proportion of the Al-Fe-Si phase is higher than the $\mathrm{Mg}_{2} \mathrm{Si}$ phase due to the dissolution of the $\mathrm{Mg}_{2} \mathrm{Si}$ phase with increasing laser power, which leads to an increase in the volume of the pits.

\section{Conclusions}

Based on the above results and discussions, the following conclusions can be obtained:

(1) With the increase of laser power, the segregation structure, equiaxed grain, and HAZ structure and columnar crystal at the fusion line are coarsening, and the dendrite gap increases. 
(2) The micro-galvanic corrosion in the 6061-T6 aluminum alloy welded joint is mainly induced by $\mathrm{Mg} 2 \mathrm{Si}$ and Fe-Al-Si intermetallic particles.

(3) The decrease in the corrosion pits is related to the lower density of intermetallic particles of intermetallic particles on the surface.

(4) The volume of corrosion pits increases with the increase of laser power.

Author Contributions: Data curation, H.Z., F.F., Z.D. and W.L.; Funding acquisition, Y.Q.; Investigation, W.L.; Methodology, Y.Q. and J.C.; Writing—original draft, H.Z., F.F. and Z.D.; Writing—review and editing, Y.Q. and J.C. All authors have read and agreed to the published version of the manuscript.

Funding: This research received no external funding.

Data Availability Statement: The data used to support the findings of this study are available from the corresponding author upon request.

Acknowledgments: This work was financially supported by the National Natural Science Foundation of China (Nos. 51975263 and 51575252).

Conflicts of Interest: The authors declare no conflict of interest.

\section{References}

1. Tucker, M.; Horstemeyer, M.F.; Whittington, W.; Solanki, K.; Gullett, P. The effect of varying strain rates and stress states on the plasticity, damage, and fracture of aluminum alloys. Mech. Mater. 2010, 42, 895-907. [CrossRef]

2. Sheng, J.; Huang, S.; Zhou, J.; Lu, J.; Xu, S.; Zhang, H. Effect of laser peening with different energies on fatigue fracture evolution of 6061-T6 aluminum alloy. Opt. Laser Technol. 2016, 77, 169-176. [CrossRef]

3. Abúndez, A.; Pereyra, I.; Campillo, B.; Serna, S.; Alcudia, E.; Molina, A.; Blanco, A.; Mayen, J. Improvement of ultimate tensile strength by artificial ageing and retrogression treatment of aluminium alloy 6061. Mater. Sci. Eng. A 2016, 668, 201-207. [CrossRef]

4. Chanyathunyaroj, K.; Phetchcrai, S.; Laungsopapun, G.; Rengsomboon, A. Fatigue characteristics of 6061 aluminum alloy subject to $3.5 \% \mathrm{NaCl}$ environment. Int. J. Fatigue 2020, 133, 105420. [CrossRef]

5. Bardel, D.; Fontaine, M.; Chaise, T.; Perez, M.; Nelias, D.; Bourlier, F.; Garnier, J. Integrated modelling of a 6061-T6 weld joint: From microstructure to mechanical properties. Acta Mater. 2016, 117, 81-90. [CrossRef]

6. Liang, W.; Rometsch, P.; Cao, L.; Birbilis, N. General aspects related to the corrosion of 6xxx series aluminium alloys: Exploring the influence of $\mathrm{Mg} / \mathrm{Si}$ ratio and Cu. Corros. Sci. 2013, 76, 119-128. [CrossRef]

7. Liang, M.; Melchers, R.; Chaves, I. Corrosion and pitting of 6060 series aluminium after 2 years exposure in seawater splash, tidal and immersion zones. Corros. Sci. 2018, 140, 286-296. [CrossRef]

8. Gungor, B.; Kaluc, E.; Taban, E.; Sik, A. Mechanical, fatigue and microstructural properties of friction stir welded 5083-H111 and 6082-T651 aluminum alloys. Mater. Des. 2014, 56, 84-90. [CrossRef]

9. Atabaki, M.M.; Ma, J.; Yang, G.; Kovacevic, R. Hybrid laser/arc welding of advanced high strength steel in different butt joint configurations. Mater. Des. 2014, 64, 573-587. [CrossRef]

10. Zhang, C.; Gao, M.; Zeng, X. Effect of microstructural characteristics on high cycle fatigue properties of laser-arc hybrid welded AA6082 aluminum alloy. J. Mater. Process. Technol. 2016, 231, 479-487. [CrossRef]

11. Arunkumar, S.; Kannan, T.D.B.; Sathiya, P. Optimization, characterization and heat treatment of TIG-welded AA2219-T87 alloy. Emerg. Mater. Res. 2019, 8, 387-393. [CrossRef]

12. Shanavas, S.; Dhas, J.E.R. Parametric optimization of friction stir welding parameters of marine grade aluminium alloy using response surface methodology. Trans. Nonferrous Met. Soc. China 2017, 27, 2334-2344. [CrossRef]

13. Liu, T.; Mu, Z.; Hu, R.; Pang, S. Sinusoidal oscillating laser welding of 7075 aluminum alloy: Hydrodynamics, porosity formation and optimization. Int. J. Heat Mass Transf. 2019, 140, 346-358. [CrossRef]

14. Xu, G.; Zheng, Z.; Cao, Q.; Hu, Q.; Li, L.; Guo, Q.; Du, B. Numerical and experimental investigation on weld formation during laser+MIG hybrid fillet welding of aluminum alloy in horizontal position. Int. J. Adv. Manuf. Technol. 2019, 102, 2683-2694. [CrossRef]

15. Xu, G.; Wu, C.; Ma, X.; Wang, X. Numerical analysis of welding residual stress and distortion in laser+GMAW hybrid welding of aluminum alloy T-joint. Acta Met. Sin. Engl. Lett. 2013, 26, 352-360. [CrossRef]

16. Gao, X.; Wu, C.; Goecke, S.; Kügler, H. Numerical simulation of temperature field, fluid flow and weld bead formation in oscillating single mode laser-GMA hybrid welding. J. Mater. Process. Technol. 2017, 242, 147-159. [CrossRef]

17. Atabaki, M.M.; Nikodinovski, M.; Chenier, P.; Ma, J.; Liu, W.; Kovacevic, R. Experimental and numerical investigations of hybrid laser arc welding of aluminum alloys in the thick T-joint configuration. Opt. Laser Technol. 2014, 59, 68-92. [CrossRef]

18. Ahmad, R.; Bakar, M. Effect of a post-weld heat treatment on the mechanical and microstructure properties of AA6061 joints welded by the gas metal arc welding cold metal transfer method. Mater. Des. 2011, 32, 5120-5126. [CrossRef]

19. Xu, G.; Li, P.; Li, L.; Hu, Q.; Zhu, J.; Gu, X.; Du, B. Influence of Arc Power on Keyhole-Induced Porosity in Laser + GMAW Hybrid Welding of Aluminum Alloy: Numerical and Experimental Studies. Materials 2019, 12, 1328. [CrossRef] 
20. Chu, Q.; Bai, R.; Jian, H.; Lei, Z.; Hu, N.; Yan, C. Microstructure, texture and mechanical properties of 6061 aluminum laser beam welded joints. Mater. Charact. 2018, 137, 269-276. [CrossRef]

21. Zhang, D.; Jin, X.; Gao, L.-X.; Joo, H.G.; Lee, K.Y. Effect of laser-arc hybrid welding on fracture and corrosion behaviour of AA6061-T6 alloy. Mater. Sci. Eng. A 2011, 528, 2748-2754. [CrossRef]

22. Rahman, A.B.M.; Kumar, S.; Gerson, A. Galvanic corrosion of laser weldments of AA6061 aluminium alloy. Corros. Sci. 2007, 49, 4339-4351. [CrossRef]

23. Gharavi, F.; Matori, K.A.; Yunus, R.; Othman, N.K.; Fadaeifard, F. Corrosion behavior of Al6061 alloy weldment produced by friction stir welding process. J. Mater. Res. Technol. 2015, 4, 314-322. [CrossRef]

24. Zhou, H.; Fu, F.; Dai, Z.; Qiao, Y.; Chen, J.; Yang, L.; Liu, W. Effect of Laser Power on Hybrid Laser-Gas Metal Arc Welding (GMAW) of a 6061 Aluminum Alloy. J. Korean Phys. Soc. 2020, 77, 991-996. [CrossRef]

25. Qiao, Y.; Tian, Z.; Cai, X.; Chen, J.; Wang, Y.; Song, Q.; Li, H. Cavitation Erosion Behaviors of a Nickel-Free High-Nitrogen Stainless Steel. Tribol. Lett. 2019, 67, 1. [CrossRef]

26. Liu, S.Y.; Li, Y.Q.; Liu, F.D.; Zhang, H.; Ding, H.T. Effects of relative positioning of energy sources on weld integrity for hybrid laser arc welding. Opt. Lasers Eng. 2016, 81, 87-96. [CrossRef]

27. Zhan, X.; Zhao, Y.; Liu, Z.; Gao, Q.; Bu, H. Microstructure and porosity characteristics of 5 A06 aluminum alloy joints using laser-MIG hybrid welding. J. Manuf. Process. 2018, 35, 437-445. [CrossRef]

28. Lei, J.; Shi, C.; Zhou, S.; Gu, Z.; Zhang, L.-C. Enhanced corrosion and wear resistance properties of carbon fiber reinforced Ni-based composite coating by laser cladding. Surf. Coat. Technol. 2018, 334, 274-285. [CrossRef]

29. Liu, J.; Rao, Z.; Liao, S.; Wang, P.-C. Modeling of transport phenomena and solidification cracking in laser spot bead-on-plate welding of AA6063-T6 alloy. Part II—Simulation results and experimental validation. Int. J. Adv. Manuf. Technol. 2014, 74, 285-296. [CrossRef]

30. Heard, D.W.; Gauvin, R.; Brochu, M. Non-equilibrium solute partitioning in a laser re-melted Al-Li-Cu alloy. Acta Mater. 2013, 61, 7432-7436. [CrossRef]

31. Aballe, A.; Bethencourt, M.; Botana, F.; Marcos, M.; Sánchez-Amaya, J.M. Influence of the degree of polishing of alloy AA 5083 on its behaviour against localised alkaline corrosion. Corros. Sci. 2004, 46, 1909-1920. [CrossRef]

32. Zhou, K.; Wang, B.; Zhao, Y.; Liu, J. Corrosion and electrochemical behaviors of 7A09 Al-Zn-Mg-Cu alloy in chloride aqueous solution. Trans. Nonferrous Met. Soc. China 2015, 25, 2509-2515. [CrossRef]

33. Ma, Y.; Zhou, X.; Huang, W.; Thompson, G.; Zhang, X.; Luo, C.; Sun, Z. Localized corrosion in AA2099-T83 aluminum-lithium alloy: The role of intermetallic particles. Mater. Chem. Phys. 2015, 161, 201-210. [CrossRef]

34. Chen, M.-A.; Ou, Y.-C.; Fu, Y.-H.; Li, Z.-H.; Li, J.-M.; Liu, S.-D. Effect of friction stirred Al-Fe-Si particles in 6061 aluminum alloy on structure and corrosion performance of MAO coating. Surf. Coat. Technol. 2016, 304, 85-97. [CrossRef]

35. Fahimpour, V.; Sadrnezhaad, S.; Karimzadeh, F. Corrosion behavior of aluminum 6061 alloy joined by friction stir welding and gas tungsten arc welding methods. Mater. Des. 2012, 39, 329-333. [CrossRef]

36. Sun, F.; Li, X.; Lu, L.; Cheng, X.; Dong, C.; Gao, J. Corrosion behavior of 5052 and 6061 aluminum ALLOYS in deep ocean environment of south China sea. Acta Met. Sin. 2013, 49, 1219. [CrossRef]

37. Wang, L.; Dong, C.F.; Zhang, D.W.; Cheng, M.; Sun, X.G.; Xiao, K.; Thee, C.; Li, X.G. Effect of Alloying Elements on Initial Corrosion Behavior of Aluminum Alloy in Bangkok, Thailand. Acta Metall. Sin. 2020, 56, 119-128.

38. Yasakau, K.A.; Zheludkevich, M.L.; Lamaka, S.V.; Ferreira, M.G. Role of intermetallic phases in localized corrosion of AA5083. Electrochim. Acta 2007, 52, 7651-7659. [CrossRef]

39. Tan, L.; Allen, T.R. Effect of thermomechanical treatment on the corrosion of AA5083. Corros. Sci. 2010, 52, 548-554. [CrossRef]

40. Qin, Q.D.; Zhao, H.L.; Li, J.; Zhang, Y.; Zhang, B.R.; Su, X.D. Microstructures and mechanical properties of TIG welded Al-Mg2Si alloy joints. J. Manuf. Process. 2020, 56, 941-949. [CrossRef]

41. Du, P.; Li, Y.L.; Yan, X.D.; Zhang, Z.H. Study on homogenization process for high quality 6061 alloy. Mater. Heat Treat. 2010, 39, 161-165. 